\title{
Prevalence of Electricity Power theft in Nueva Ecija II Electric Cooperative, inc. (NEECO-II)-
} Area 2

\author{
Dennis Duane C. Sotto, Norman M. Pascual, Rocky L. Sison, Allan A. Trajano \\ and Noel T. Florencondia
}

\begin{abstract}
This research focused on the prevalence of electricity power theft in areas covered by NEECO IIArea 2. The data from the Special Energy Recovery Group (Apprehension Group) revealed that there were 386 apprehended electric pilferers from 2014-2016 and that the towns of Sta. Rosa and San Leonardo recorded the highest number of consumers and also have the highest number of electric pilferers as compared to other towns covered by NEECO II - Area 2.

Among all the types of electric theft, the jumper is the most prevalent in areas covered by NEECO II - Area 2 from 2014-2016. Based on data available, the towns of Sta. Rosa registered the highest number of electric power theft by means of jumper (91) and illegal connection (30), followed by the town of Gen. Tinio (42), San Leon ardo (32), Peñaranda (32), Bongabon (23), Gen. Natividad (16) and the rest of the towns are minimal in number. By comparing the total number of electric power theft regardless of its type, the year 2014 registered the highest number of violators (173) and significantly decrease in the year 2015 and 2016 (119 and 95, respectively) and up to August 2017 (39).

Based on the computation from the Special Energy Recovery Group (Apprehension Group) and that of the Finance Department, the total non-technical losses occurred from 2014-2016 was 6.50\% and it is equivalent to P81,464,791.83 or on the average P2,292,910.88 per month. Losses can be even higher because the actual nontechnical losses cannot be easily detected, meaning the apprehended party might consume higher than the average consumption because as being said, it is electric theft.
\end{abstract}

Keywords-electricity, direct hooking, non-technical loss, consumers, losses.

\section{INTRODUCTION}

In many countries, including the Philippines, electric system loss is common and comprise of three components: the administrative loss, the technical loss, and the non-technical loss. The latter constitute the electricity theft, which includes jumper/illegal connection (direct hooking), meter tampering (injecting foreign element into the electric meter and physical obstruction).

Electricity theft is the use of electrical power without the knowledge of the supplier with total or partial used by passing a metering system or such as interfere this system in the way to adulterate its measurements. The electricity theft by a consumer essentially bears some risk of being detected and be fined. It is a criminal practice and is punishable by law.

The financial losses are critical to many electric power organizations [1]. Electricity theft in effect deteriorates the financial condition of the electric utility provider, curtails new investments for capacity development that eventually leads to electricity shortage. But, the financial loss is high due to a large amount of electricity distributed [1]. Huge losses adversely affect the utilities' profitability and consequently, the quality of service it provides to its consumers. The losses include technical, non-technical and that mainly constitutes electricity pilferage and theft. The financial loss due to electricity theft accounts for a considerable and valuable amount, which can result in debt and hurts future investment for capacity additions. Such losses can be used for other operation by the electric utility provider. An effort is needed to prevent electricity theft by restricting dishonesty among utility employees and consumers.

Electricity theft is an economic issue for the electricity company due to the unbilled revenue of consumers who 
commit such action. In a regulated scenario, the company needs to fit within the laws of a regulatory agency and the loss of revenue is a problem that can compromise the compliance with regulatory targets and business efficiency [2].

Moreover, with the number of cases of energy theft on the increase, isn't just a matter of monetary theft, but can have detrimental consequences for the building's occupants, increasing the risk of electrical fire, gas leaks and explosions [3].

In the Philippines, although there is a law about the pilferage of electricity and theft of electric power transmission lines/materials(R.A.7832)[4], the prevalence of pilferage is very evident in most of the towns and municipalities.

That is why this study was conducted. The researchers who are engineers want to investigate the prevailing concerns of electricity theft in the Nueva Ecija II Electric Cooperative, Inc. - Area 2 (NEECO II - Area 2) located at Nueva Ecija, Philippines. It is an electric power provider of 10 municipalities and one chartered city. It covers the towns of Sta. Rosa, San Leonardo, Peñaranda, Gen. Tinio, Bongabon, Rizal, Llanera, Gen. Natividad, Laur, Gabaldon and the City of Palayan. NEECO II-Area 2 coverage area is composed of ten (10) municipalities and one (1) chartered city and is divided into three (3) Zones. Zone I is composed of the municipalities of Sta. Rosa, San Leonardo, Gen. Tinio, and Penaranda. Zone II is composed of the City of Palayan and towns of Bongabon, Laur and Gabaldon while Zone III is composed of the municipalities of Rizal, Llanera and Gen. M. Natividad. It is under the supervision of National Electrification Administration (NEA) and has currently 105,785 consumers and was established during the early '90sunder the name of National Electrification Management Team(NMT) and in November 2004changes its name to NEECO II-Area 2 [5].This research focused on three-year (2014-2016) electric theft in NEECO II-Area 2. It described the prevalence and types of electricity theft among the different towns covered by NECCO II- Area 2 as well as recommendations to avoid electric theft within the service areas.

\section{METHODOLOGY}

For practical and valid reasons, the researchers used the mixed approach to research combining in one study two research strategies, namely: a survey (quantitative) and process documentation (des criptive). According to [6], the purpose of survey research is to "generalize from a sample to a population so that inferences can be made about some characteristic, attitude or behavior of this population." In addition to the survey, the researchers used process documentation (PD). According to Korten (2008), as cited by [7],"PD is a collection of available data on a project to provide learning and to check objectives, to set working methods, to develop a monitoring system and human resource development planning."

The researchers used records available in the Customer Services Department, Technical Services Department, Finance Services Department, Special Energy Recovery Group (Apprehension Group) in data collection for the quantitative aspect of the study.

The respondents who were interviewed were chosen purposively based on the following criteria [8]: they were technical manager who manages the day to day operation of the cooperative regarding technical matters; finance division chief who was tasked to oversee the financial matters of the cooperative; the chief of consumer services division who in-charge with customer-related concerns; and the head of Special Energy Recovery Group and its personnel who were tasked to look into the violations committed by the offenders.

To determine the total number of electric consumers in every town covered by NEECO II- Area 2, the list was taken from the Consumer Services Department of NEECO II - Area 2 in San Leonardo, Nueva Ecija. For the sociodemographic profile of electric pilferers (question 2) the researcher used frequency count and percentages.

\section{RESULTS AND DISCUSSION}

Based on the records available from the Customer Services Division, there are 105,785 consumers as of August 2017 from the ten towns and one city covered by NEECO II Area 2. 


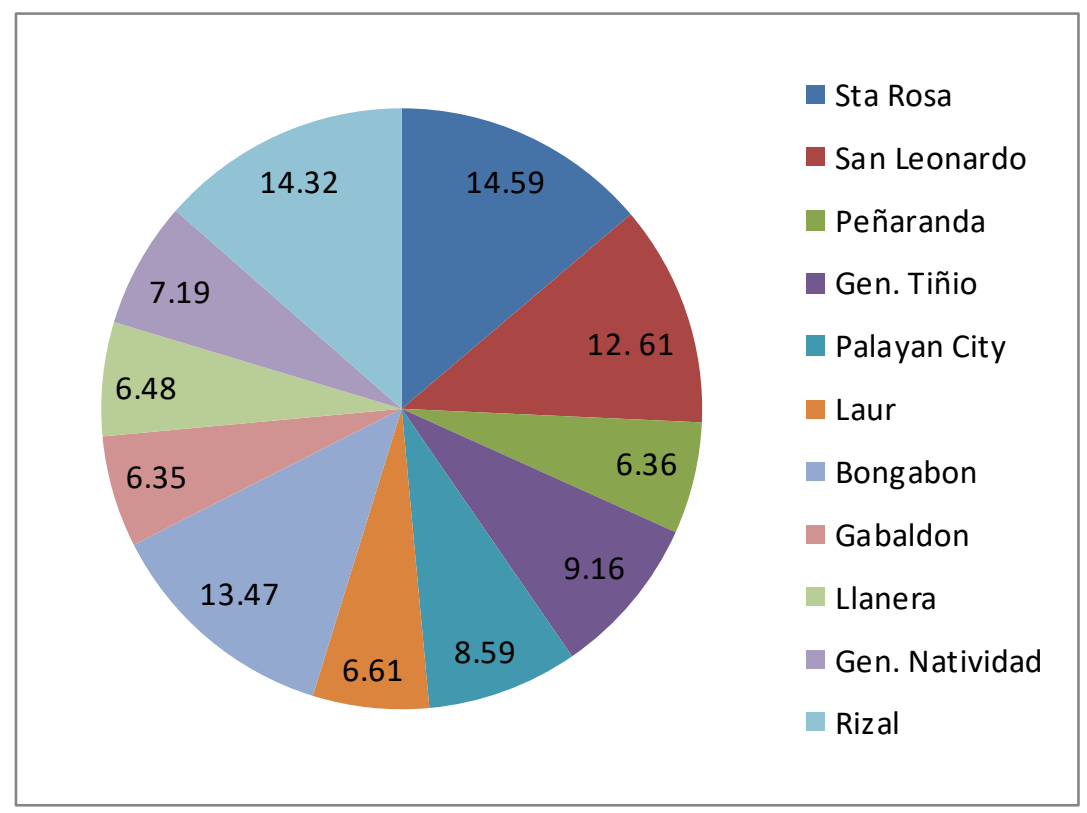

Fig.1: Total number of NEECO II - Area 2 consumers as of August 2017

Based on the data presented above, the towns of Sta. Rosa and Rizal comprise the largest number of consumers (14,594 and 14,325, respectively), followed by Bongabon (13,476), San Leonardo (12,615), Gen. Tiñio $(9,166)$, Palayan City $(8,597)$, Gen. Natividad (7,191), Laur (6,616), Llanera (6,481) Gabaldon (6,359), and Peñaranda $(6,366)$.

Table.1: Total Number of Consumers of NEECO II- Area 2 from 2014-2016

\begin{tabular}{|c|c|c|c|}
\hline Year & 2014 & 2015 & 2016 \\
\hline Electric Consumers & 95,471 & 99,023 & 102,937 \\
\hline
\end{tabular}

Based on the data above, the total number of consumers' difference in 2015 against that of 2014 is 3,552 and 3,914 in 2016 against that of 2015. As shown in Table 2, data from the Special Energy Recovery Group (Apprehension Group) revealed that there were 386 apprehended electric pilferers from 2014-2016 and are as follows:

Table.2: Total Number of Apprehended Electric Pilferers

\begin{tabular}{|l|c|c|c|c|}
\hline \multirow{2}{*}{$\begin{array}{c}\text { NEFCO II Area 2 } \\
\text { Coverage Area }\end{array}$} & \multicolumn{2}{c|}{ Year } & \multirow{2}{*}{ Apprehended } \\
\cline { 2 - 5 } & $\mathbf{2 0 1 4}$ & $\mathbf{2 0 1 5}$ & $\mathbf{2 0 1 6}$ & 132 \\
\hline Sta. Rosa & 74 & 38 & 20 & 84 \\
\hline San Leonardo & 23 & 25 & 36 & 43 \\
\hline Gen. Tinio & 19 & 12 & 12 & 42 \\
\hline Peñaranda & 18 & 21 & 3 & 32 \\
\hline Bongabon & 11 & 9 & 12 & 16 \\
\hline Gen. Natividad & 11 & 5 & 0 & 15 \\
\hline Palayan City & 4 & 2 & 9 & 10 \\
\hline Rizal & 6 & 2 & 2 & 5 \\
\hline Laur & 3 & 1 & 1 & 5 \\
\hline Gabaldon & 3 & 2 & 0 & 2 \\
\hline Gen. Llanera & 1 & 1 & 0 & $\mathbf{3 8 6}$ \\
\hline Total & & & \\
\hline
\end{tabular}


The towns of Sta. Rosa and San Leonardo recorded the highest number of consumers but also registered the highest number of electric pilferers (132 and 84, respectively) as compared to other towns covered by NEECO II - Area 2. It is being followed by the towns ofGen. Tinio (43), Peñaranda (42), Bongabon (32), Gen. Natividad (16), Palayan City (15), Rizal (10), Laur (5) Gabaldon (5), and
Gen. Llanera (2). The towns which are located on the southern part of Nueva Ecija (Sta. Rosa, San Leonardo, Gen. Tinio, and Peñaranda) recorded the most number of electric pilferers while the eastern towns and city of Nueva Ecija (Bongabon, Gen. Natividad, Palayan City, Rizal, Laur, Gabaldon, and Gen. Llanera) recorded the least number of electric pilferers.

Table.3: Different types of electric thefts in areas covered by NEECO II-Area 2 from 2014-2016 as compared up to August of

\begin{tabular}{|c|c|c|c|c|c|c|}
\hline \multirow{2}{*}{$\begin{array}{c}\text { NEECO II Area } 2 \\
\text { Coverage Area }\end{array}$} & \multirow{2}{*}{$\begin{array}{c}\text { Types of Electric Pilferage } \\
\text { Violations }\end{array}$} & \multicolumn{5}{|c|}{ Year } \\
\hline & & 2014 & 2015 & 2016 & SubTotal & 2017 \\
\hline \multirow{4}{*}{ Sta. Rosa } & $\begin{array}{l}\text { Jumper/illegal connection (direct } \\
\text { hooking) }\end{array}$ & 68 & 33 & 18 & 119 & 8 \\
\hline & Suspended neutral & 5 & 3 & 3 & 11 & 0 \\
\hline & Tampered meter & 0 & 2 & 0 & 2 & 1 \\
\hline & Illegal grounding & 1 & 0 & 0 & 1 & 0 \\
\hline \multirow{4}{*}{ San Leonardo } & $\begin{array}{l}\text { Jumper/illegal connection (direct } \\
\text { hooking) }\end{array}$ & 19 & 15 & 15 & 49 & 6 \\
\hline & Suspended neutral & 3 & 3 & 2 & 8 & 0 \\
\hline & Tampered meter & 0 & 7 & 19 & 26 & 0 \\
\hline & Illegal grounding & 1 & 0 & 0 & 1 & 0 \\
\hline \multirow{4}{*}{ Gen. Tinio } & $\begin{array}{l}\text { Jumper/illegal connection (direct } \\
\text { hooking) }\end{array}$ & 18 & 12 & 12 & 42 & 0 \\
\hline & Suspended neutral & 1 & 0 & 0 & 1 & 0 \\
\hline & Tampered meter & 0 & 0 & 0 & 0 & 0 \\
\hline & Illegal grounding & 0 & 0 & 0 & 0 & 0 \\
\hline \multirow{4}{*}{ Peñaranda } & $\begin{array}{l}\text { Jumper/illegal connection (direct } \\
\text { hooking) }\end{array}$ & 16 & 19 & 3 & 38 & 2 \\
\hline & Suspended neutral & 2 & 2 & 0 & 4 & 0 \\
\hline & Tampered meter & 0 & 0 & 0 & 0 & 1 \\
\hline & Illegal grounding & 0 & 0 & 0 & 0 & 0 \\
\hline \multirow{4}{*}{ Bongabon } & $\begin{array}{l}\text { Jumper/illegal connection (direct } \\
\text { hooking) }\end{array}$ & 11 & 9 & 3 & 23 & 20 \\
\hline & Suspended neutral & 0 & 0 & 1 & 1 & 0 \\
\hline & Tampered meter & 0 & 0 & 8 & 8 & 0 \\
\hline & Illegal grounding & 0 & 0 & 0 & 0 & 0 \\
\hline \multirow{4}{*}{ Gen. Natividad } & $\begin{array}{l}\text { Jumper/illegal connection (direct } \\
\text { hooking) }\end{array}$ & 11 & 5 & 0 & 16 & 0 \\
\hline & Suspended neutral & 0 & 0 & 0 & 0 & 0 \\
\hline & Tampered meter & 0 & 0 & 0 & 0 & 0 \\
\hline & Illegal grounding & 0 & 0 & 0 & 0 & 0 \\
\hline
\end{tabular}




\begin{tabular}{|c|c|c|c|c|c|c|}
\hline \multirow{4}{*}{ Palayan City } & $\begin{array}{l}\text { Jumper/illegal connection (direct } \\
\text { hooking) }\end{array}$ & 3 & 2 & 8 & 13 & 1 \\
\hline & Suspended neutral & 1 & 0 & 1 & 2 & 0 \\
\hline & Tampered meter & 0 & 0 & 0 & 0 & 0 \\
\hline & Illegal grounding & 0 & 0 & 0 & 0 & 0 \\
\hline \multirow{4}{*}{ Rizal } & $\begin{array}{l}\text { Jumper/illegal connection (direct } \\
\text { hooking) }\end{array}$ & 6 & 2 & 2 & 10 & 0 \\
\hline & Suspended neutral & 0 & 0 & 0 & 0 & 0 \\
\hline & Tampered meter & 0 & 0 & 0 & 0 & 0 \\
\hline & Illegal grounding & 0 & 0 & 0 & 0 & 0 \\
\hline \multirow{4}{*}{ Laur } & $\begin{array}{l}\text { Jumper/illegal connection (direct } \\
\text { hooking) }\end{array}$ & 3 & 1 & 0 & 4 & 0 \\
\hline & Suspended neutral & 0 & 0 & 0 & 0 & 0 \\
\hline & Tampered meter & 0 & 0 & 0 & 0 & 0 \\
\hline & Illegal grounding & 0 & 0 & 0 & 0 & 0 \\
\hline \multirow{4}{*}{ Gabaldon } & $\begin{array}{l}\text { Jumper/illegal connection (direct } \\
\text { hooking) }\end{array}$ & 3 & 2 & 0 & 5 & 0 \\
\hline & Suspended neutral & 0 & 0 & 0 & 0 & 0 \\
\hline & Tampered meter & 0 & 0 & 0 & 0 & 0 \\
\hline & Illegal grounding & 0 & 0 & 0 & 0 & 0 \\
\hline \multirow{4}{*}{ Gen. Llanera } & $\begin{array}{l}\text { Jumper/illegal connection (direct } \\
\text { hooking) }\end{array}$ & 1 & 1 & 0 & 2 & 0 \\
\hline & Suspended neutral & 0 & 0 & 0 & 0 & 0 \\
\hline & Tampered meter & 0 & 0 & 0 & 0 & 0 \\
\hline & Illegal grounding & 0 & 0 & 0 & 0 & 0 \\
\hline \multicolumn{2}{|l|}{ Total } & 173 & 118 & 95 & 386 & 39 \\
\hline
\end{tabular}

Among all the types of electric theft, jumper/illegal connection (direct hooking) is the most prevalent in areas covered by NEECO II - Area 2 from 2014-2016. Based on data available, the towns of Sta. Rosa registered the highest number of electric power theft by means of jumper or direct hooking (119)followed by the town of San Leonardo(49), Gen. Tinio (42), Peñaranda (38), Bongabon (23), Gen.
Natividad (16) and the rest of the towns are minimal in number.

By comparing the total number of electric power theft regardless of its type, the year 2014 registered the highest number of violators (173) and significantly decrease in the year 2015 and 2016 (118 and 95, respectively) and up to August 2017 (39).

Table.4: Percentage of Non-Technical Losses from 20014-2016

$\left.\begin{array}{|c|c|}\hline \text { Year } & \text { \% Non-Technical Loss from 2015-2016 } \\ \hline 2014 & 2.1 \\ \hline 2015 & 2.4 \\ \hline 2016 & 2.0\end{array}\right\}$

Based on the computation from the Special Energy Recovery Group (Apprehension Group) and that of the Finance Department, the total non-technical losses occurred from 2014-2016 was $6.50 \%$ and it is equivalent to P81,464,791.83 or on the average P2,292,910.88 per month. Losses can be even higher because the actual non-technical 
losses cannot be easily detected, meaning the apprehended

because as being said, it is electric theft. party might consume higher than the average consumption

Table.5: Comparison of Revenue, Expenses and Income of NEECO II- Area 2 from 2014-2016

\begin{tabular}{|l|c|c|c|}
\hline & 2014 & 2015 & 2016 \\
\hline Sales & $1,202,456,000.00$ & $1,386,144,989.00$ & $1,147,286,805.00$ \\
\hline Expenses & $1,189,223,159.00$ & $1,385,963,610.00$ & $1,128,566,580.00$ \\
\hline Income & $13,232,841.00$ & $181,379.00$ & $18,720,225.00$ \\
\hline
\end{tabular}

Considering the number of consumers from 2014-2016, there was a significant increase in the sales of the utility by electric power provider. However, as compared to the income of 2015 it is significantly lower because Nueva Ecija was struck by typhoon Lando sometime in October 2015. Majority of the sales were allotted for the rehabilitation of lines in areas covered by NEECO II-Area 2. If the damaged power lines are not rehabilitated on time, the service and supply of electricity among consumers will not be made possible. Thus, it will result in more financial losses on the part of the company. As compared to the three years operation, the year 2016 earned the highest income because it is attributed to the increase in several consumers and a significant decrease in the number of electric power theft incidence as shown in Tables 1 and 3, respectively. If electric power theft continues, losses amounting to millions of pesos, it can be said that primarily, the quality of operational efficiency among its consumers by the utility provider is being compromised. Also, administrative efficiency, human resources development (trainings/skills acquisition), operation and maintenance as well as rehabilitation of power lines, etc.,are at stake.

If the non-technical may persist, the consumers, as provided by RA 7832 (Sec.12), and under its implementing rules and regulations (IRR), allow private distribution utilities and rural cooperatives to retrieve their electricity costs as part of their system loss. In short, the honest consumers will be the one to shoulder the actual system losses being committed by apprehended electric pilferers. Though electricity theft can be minimized by upgrading the facilities of the utility distributor, the consumers will be the one to shoulder a high rate of electric charges (billing).

\section{CONCLUSIONS AND RECOMMENDATIONS}

The towns of Sta. Rosa and Rizal comprise the largest number of consumers followed by Bongabon, San Leonardo, Gen. Tiñio, Palayan City, Gen. Natividad, Laur,
Llanera, Gabaldon, and Peñaranda. The data from the Special Energy Recovery Group (Apprehension Group) revealed that there were 386 apprehended electric pilferers from 2014-2016 and that the towns of Sta. Rosa and San Leonardo recorded the highest number of consumers but also registered the highest number of electric pilferers as compared to other towns covered by NEECO II - Area 2.Among all the types of electric theft, the jumper is the most prevalent in areas covered by NEECO II - Area 2 from 2014-2016. Based on data available, the towns of Sta. Rosa registered the highest number of electric power theft by means of jumper (91) and illegal connection (30), followed by the town of Gen. Tinio (42), San Leonardo (32), Peñaranda (32), Bongabon (23), Gen. Natividad (16) and the rest of the towns are minimal in number. By comparing the total number of electric power theft regardless of its type, the year 2014 registered the highest number of violators (173) and significantly decrease in the year 2015 and 2016 (119 and 95, respectively) and up to August 2017 (39).

Based on the computation from the Special Energy Recovery Group (Apprehension Group) and that of the Finance Department, the total non-technical losses occurred from 2014-2016 was 6.50\% and it is equivalent to P81,464,791.83 or on the average P2,292,910.88 per month. Losses can be even higher because the actual non-technical losses cannot be easily detected, meaning the apprehended party might consume higher than the average consumption because as being said, it is electric theft.

Due to the high prevalence of electric theft in the town of Sta. Rosa and San Leonardo, the following are being recommended: installeither smart meter or pre-paid meter in barangays where there is a high registry of apprehended electric pilferers. This can be done on a staggered basis and should be included in the rehabilitation program of NEECO II. Strict implementation of R.A. 7832 should be imposed. Likewise, it is also recommended by the researchers to study, compare and explore the performances [9] of 
different NEECO Areas regarding their programs in stopping electricity theft from being able to make accurate decisions given available information [10] to have a much more effective plan in preventing electricity pilferage in Nueva Ecija.

\section{REFERENCES}

[1] Gangwal, H.(2016). Electricity Theft Control Using Microcontroller. https://docshare.tips/electricity-theftcontrol-usingmicrocontroller 576ca462b6d87f51328b49cd.html

[2] Arango, et.al.(2017).Study of Electricity Theft Impact on the Economy of a Regulated Electricity Company. Journal of Control, Automation and Electrical Systems. DOI 10.1007/s40313-017-0325-z.

[3] Gazprom Energy.(2017). What your business needs to know about the dangers of energy theft. https://www.gazpromenergy .co.uk/blog/what-y our-business-needs-to-know-aboutthe-dangers-of-energy-theft/

[4] Republic Act $\quad$ No. 7832. https://www.lawphil.net/statutes/repacts/ra1994/ra 783219 94.html

[5] 2014-2016 NEECO II - Area 2 Annual Report: San Leonardo, Nueva Ecija, Phils.

[6] Creswell J.W. (2003). Research Design: Qualitative, quantitative, and mixed methods approach. Sage Publications: California, USA.

[7] Catabona, Z. (2015). Nursing in-house review initiatives: A process documentation. Unpublished research. M.V. Gallego Foundation Colleges, Inc.: Cabanatuan City.

[8] Subia, G.S. (2018). Comprehensible Technique in Solving Consecutive Number Problems in Algebra. Journal of Applied Mathematics and Physics, 6,447-457. https://doi.org/10.4236/jamp.2018.63041

[9] Subia, G., Amaranto, J., Amaranto, J., Bustamante, J. and Damaso, I. (2019) Chess and Mathematics Performance of College Players: An Exploratory Analysis. Open Access Library Journal, 6, 1-7. doi: 10.4236/oalib.1105195

[10] Subia, Gener S. (2018). Think Like My Teacher (TLMT): A New Method in Assessing Millennial Learners. International Journal of Arts, Humanities and Social Sciences.Volume 3. Issue 1.www.ijahss.com 